\title{
The Status of Three Species of Turacos in the Kakum Conservation Area in the Central Region, Ghana
}

\author{
S. Yeboah ${ }^{1 *}$, J. P. Deikumah ${ }^{1}$ and E. Henaku-Owusu ${ }^{2}$ \\ ${ }_{1}$ Department of Entomology and Wildlife, University of Cape Coast, Cape Coast, Ghana \\ ${ }^{2}$ Ghana Wildlife Society, Accra, Ghana \\ *Corresponding author; E-mail: ssyeboah@yahoo.com
}

\begin{abstract}
The encounter rates and relative abundance of three species of turacos, namely great blue (Corythaeola cristata), green (Tauraco persa) and yellow-billed (Tauraco macrorynchus) were studied in tropical rainforest in the Kakum Conservation Area (KCA) in the Central Region of Ghana between August 2005 and June 2006. The transect count method was employed in recording all turaco contacts. Turaco numbers and encounter rates varied among the four study sites. Both green and yellow-billed turacos were relatively common in the study area. Great blue turacos were, however, very few in the KCA and, therefore, need some protective and conservation attention. Turacos were restricted to the more pristine parts of the KCA than in secondary forest, where the encounter rates were also relatively lower ( 0 and 2.17 individuals/h in primary and secondary forests, respectively). The relative abundance and encounter rates of turaco species also varied between the seasons of the year, with larger numbers being encountered in the major rainy season (June-July). The most suitable areas for turaco-bird watching have been identified to be in the primary forests, especially near Antwikwaa camps, and a comprehensive study of the ecology of turacos in the KCA to facilitate their conservation has also been suggested.
\end{abstract}

\section{Introduction}

Turacos are endemic to Africa south of Sahara where they live in a variety of habitats. They are medium to large-sized arboreal birds with crested heads and long tails (Hanzak, 1974; Borrow \& Demey, 2001). The sexes are similar externally, with weak flights over only short distances consisting of some flaps followed by a glide.

Turacos belong to the order Cuculiformes together with cuckoos, roadrunners and the hoatzin, in three distinct families in this order (Verheyen, 1956). Turacos belong to the family Musophagidae and Tauraco is the largest of the five genera, the other four being Corythaeola, Corythaixoides, Crinifer and Musophaga (Grimes, 1987).

Turacos are pigeon-sized birds measuring about $33 \mathrm{~cm}$ from beak to tail, but the great blue turaco is the largest at $90 \mathrm{~cm}$ long and weighing $1.1 \mathrm{~kg}$. Their feet are described as semi-zygodactylous because the fourth toe points out sideways, forwards or backwards at will. They form small flocks in tree tops, and are adequate, though not expert, flyers. They are very agile on their feet and happily run around in the vegetation. They are noisy and sociable birds and very vocal, with loud resonant hourly calls, being one of the most characteristic sounds of the African rainforest (Dowsett-Lemaire, 1990).

Turacos are primarily hervivores, feeding on fruits and seeds, and occasionally insects and other invertebrates. They are considered to be principally frugivorous (Brosset \& Fry, 1988) and, given their large body sizes, they may be important seed dispersers in African tropical forest (Dowsett-Lemaire, 1983, 1990; Brosset \& Erard, 1986; Brosset \& Fry, 1988). Nests of turacos are made of figs and placed low in the vegetation. The eggs are of various colours and normally two or three are laid and incubated by the female for only 18 days. The young are born altricial, and fed on regurgitated fruit for about 4 weeks, by which time they are able to fly and forage for themselves.

The Kakum Conservation Area (KCA) in the Central Region of Ghana is located in the tropical rainforest zone and habours all the three species of turacos in Ghana: green- crested turaco (Tauraco corythaix persa), yellow-billed (Tauraco macrorynchus) and the great blue turaco (Corythaeola cristata) (Borrow \& Demey, 2001). Little knowledge exists on the turacos in the area, apart from recent West African Journal of Applied Ecology - Volume 13 
inventories (Dowsett-Lemaire, 1983; 1990; Brosset \& Fry, 1988; Birdlife International, 2004). According to Birdlife International (2004), all the three species are rare wherever they occur and, therefore, require conservation attention. Research on the distribution and relative abundance of these turacos in their natural habitat such as the KCA, is an important step towards enhancing their conservation and tourism potential.

Study area

\section{Materials and methods}

The study took place at the Kakum Conservation Area (KCA), comprising Kakum National Park (KNP) and the adjacent Assin Attandanso Resource Reserve (AARR). The KCA is located in the Central Region of Ghana (Fig.1), and the two reserve categories (KNP and AARR) were forest reserves until 1989 when they were placed under protection by the Ghana Wildlife Division of the Forestry Commission (MensahNtiamoah, 1989).

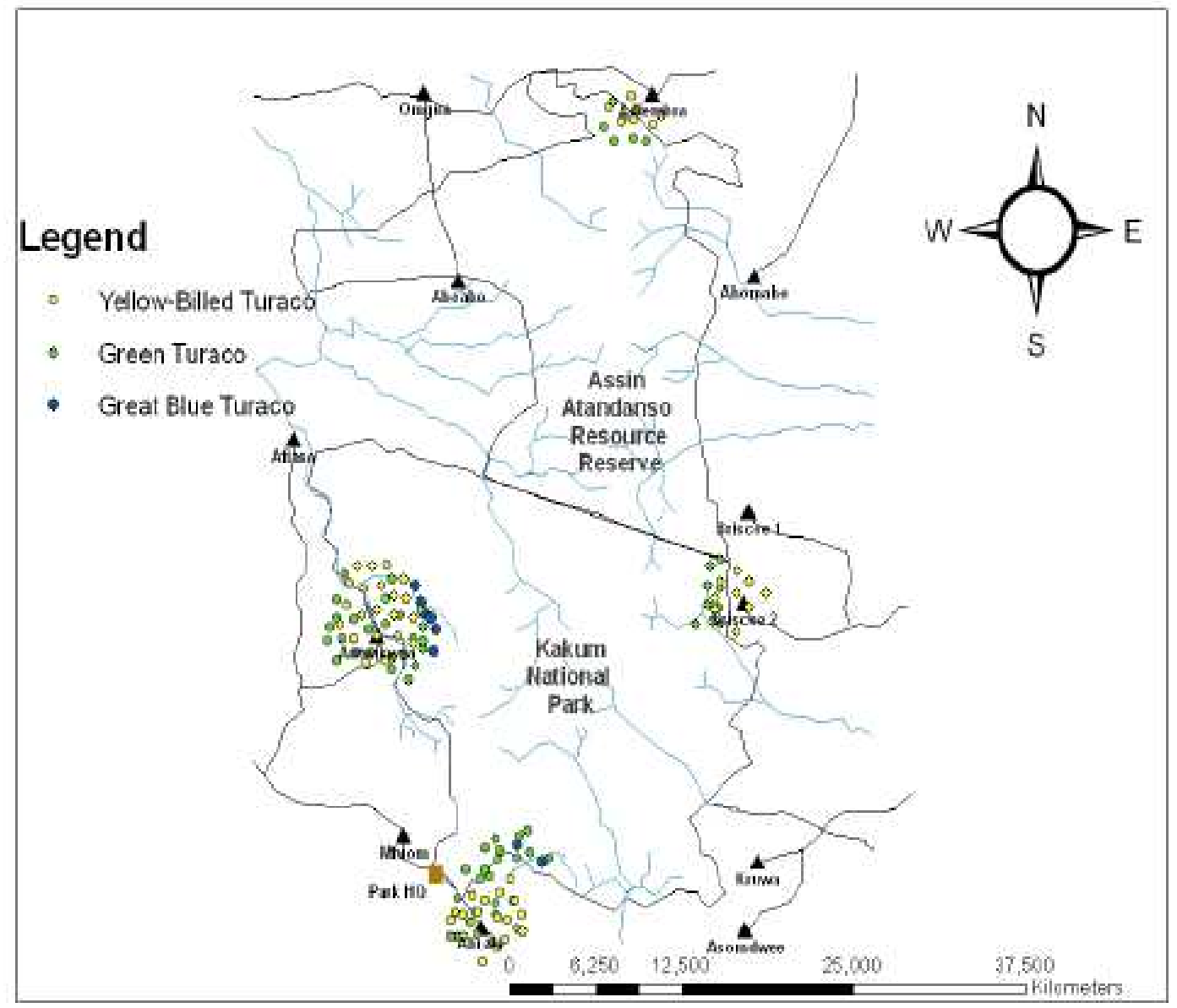

Fig. 1. The four study sites showing the distribution and relative abundance of Turaco species in the KCA

The area has two peak rainy seasons, the major season in May-June and the minor, SeptemberOctober (Hall \& Swaine, 1981; Mensah-Ntiamoah, 1989). The vegetation is moist semi-deciduous forest, and the two contiguous reserves form an irregular block as part of the upper Guinean rainforest of West

West African Journal of Applied Ecology - Volume 13 
Africa (Hall \& Swaine, 1981; Mensah- Ntiamoah, 1989). Six Wildlife Division designated camps, sited in six of the villages bordering the Park, are spread around the KCA. Four of the camps were selected as study sites: Abrafo, Antwikwaa, Briscoe II and Adiembra (Fig.1).

Two $3 \mathrm{~km}$-long line transects were laid in each of the four study sites (Fig. 1) using Global Positioning System (GPS) to locate the coordinates. The two transects in each site were about $0.7 \mathrm{~km}$ apart, and were cut such that they were parallel to each other. This was to avoid double counting of a particular species of the turacos. Flagging tapes were used to indicate location of transects, and the GPS coordinates of transects were also taken at the beginning and the end of each transect. Each transect was sampled twice a day (morning and afternoon) for 3 days giving a total of six samplings per transect (Bibby et al., 1998). At each study site, one transect was placed in pristine vegetation and the other in a disturbed or secondary vegetation since vegetation type is known to influence species diversity and richness (Perrins \& Birkhead, 1983).

Daily observations of the turacos started early in the morning, from $06.00 \mathrm{~h}$ GMT to $10.00 \mathrm{~h}$ GMT in the morning and from $14.00 \mathrm{~h}$ GMT to $17.00 \mathrm{~h}$ GMT in the afternoon because birds are known to have two feeding bouts (Perrins \& Birkhead, 1983; Bibby et al., 1998). Transects were walked at constant speed with very little disturbance. A pair of binoculars $(7 \times 35 \mathrm{~m})$ was used to watch the turacos through openings in the vegetation on top of very tall trees ranging in height from about $40 \mathrm{~m}$ to $70 \mathrm{~m}$. The different turacos species were also identified from their calls, and this involved walking about $100-200 \mathrm{~m}$ away from the main transects to wait for the next call while using the binoculars to search the canopy (Bibby et al., 1998; Borrow \& Demey, 2001)

The frequency of sighting and hearings of the turacos was used to determine the commonness of the species in the various study sites according to the Helm Identification Guides (Birds of Western Africa) (Borrow \& Demey, 2001). Along each transect, contacts with the birds were recorded by sight and sound in their natural habitats. The distinctive calls of the three species were compared with recorded calls for identification (Borrow \& Demey, 2001). The potential of incorporating turaco viewing into the park's tourism-enhancing program-mes was investigated by determining the preferred habitats of the turacos, and recording them using GPS and extrapolating on the park map.

The encounter rates for each broad habitat type (primary forest and logged forest) were determined (Bibby et al., 1998) from:

Encounter rate $=\frac{\text { Number of turacos recorded }}{\text { Number of hours spent searching }}$

Species distribution and relative abundance

\section{Results}

Both Tauraco persa (green turaco) and Tauraco macrorynchus (yellow-billed turaco) were very common (more than 30 individuals) in Abrafo, Antwikwaa and Briscoe II, and common (21-30 individuals) in Adiembra. The great blue turacos (Corythaeola cristata) were rather few in Abrafo and Antwikwaa and not found at all in Briscoe II, and Adiembra (Table 1).

TABLE 1

Turaco species and their relative abundance in the forest near the camps. (Observation over time effort of 18 her camp site per season)

\begin{tabular}{llccc} 
Species & \multicolumn{4}{c}{ Camps and number of individual species } \\
& Abrafo & Antwikwaa & Briscoe II & Adiembra \\
& & & & 0 \\
Corythaeola cristata & + & ++ & 0 & +++ \\
Tauraco persa & ++++ & +++ & +++ & +++ \\
Tauraco macrorynchus & ++++ & ++++ & +++ & +++
\end{tabular}

West African Journal of Applied Ecology - Volume 13 
$+=$ Very few (1-10 individuals); ++ = Few (11-20 individuals); + ++ = Common (21-30 individuals);

$++++=$ Very common (> 30 individuals); $0=$ Not found.

The number of individuals of each turaco species encountered varied from one camp (study site) to the other, and also with the seasons (Table 2, Fig. 2). Thirteen individuals (76.5\%) of Corythaeola cristata were encountered at Antwikwaa forest out of the 17 individuals encountered during the study. The remaining four individuals (23.5\%) were encountered at Abrafo Camp. Antwikwa recorded the highest number of individuals of Corythaeola cristata during the study period, with four, three, and six individuals in the minor rainy, dry and major rainy seasons, respectively. For all the species, more individuals were encountered during the rainy season than the dry season (Table 2).

TABLE 2

Average number of individual turaco species encountered in the camps (study sites) during the various seasons

\begin{tabular}{|c|c|c|c|c|c|c|}
\hline \multirow[t]{2}{*}{ Species } & \multirow[t]{2}{*}{ Seasons } & \multicolumn{4}{|c|}{ Camps } & \multirow{2}{*}{ Total } \\
\hline & & Abrafo & Antwikwa & Briscoe II & Adiembra & \\
\hline \multirow[t]{4}{*}{ Corythaeola cristata } & Minor rainy & 2 & 4 & 0 & 0 & 6 \\
\hline & Dry & 0 & 3 & 0 & 0 & 3 \\
\hline & Major rainy & 2 & 6 & 0 & 0 & 8 \\
\hline & Total & 4 & 13 & 0 & 0 & 17 \\
\hline \multirow[t]{4}{*}{ Tauraco persa } & Minor rainy & 14 & 15 & 13 & 7 & 49 \\
\hline & Dry & 6 & 10 & 8 & 6 & 30 \\
\hline & Major rainy & 15 & 17 & 13 & 9 & 54 \\
\hline & Total & 35 & 42 & 34 & 22 & 133 \\
\hline \multirow[t]{4}{*}{ Tauraco macrorynchus } & Minor rainy & 9 & 5 & 7 & 3 & 24 \\
\hline & Dry & 3 & 6 & 6 & 4 & 19 \\
\hline & Major rainy & 9 & 13 & 7 & 6 & 35 \\
\hline & Total & 21 & 24 & 20 & 13 & 78 \\
\hline
\end{tabular}

West African Journal of Applied Ecology - Volume 13 


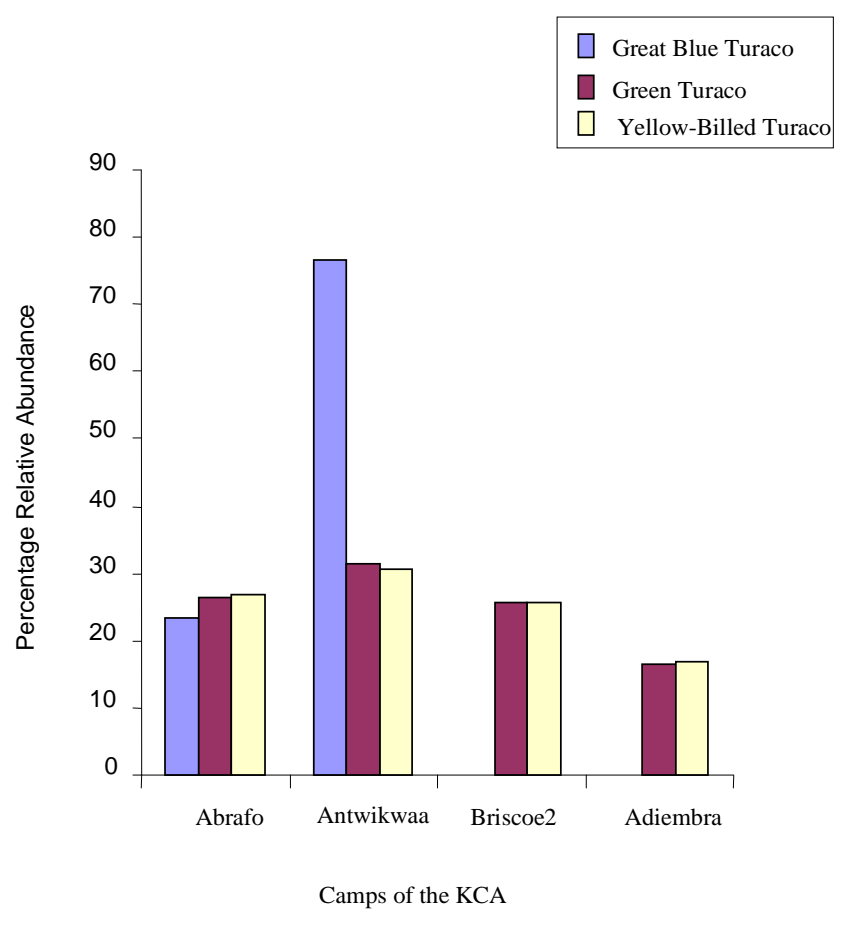

Fig. 2. Relative Abundance of Turaco species in the KCA

A total of $42(31.6 \%)$ out of 133 individuals of T. persa were recorded at Antwikwaa, 35 individuals (26.3\%) at Abrafo, 34 individuals (25.6\%) at Briscoe II, and 22 individuals (16.5\%) at Adiembra. Antwikwaa also recorded the highest number of individuals of T. macrorynchus (24 individuals) representing $30.8 \%$ of the total of 78 individuals encountered in the KCA with Adiembra recording the least number with 13 individuals (16.7\%) (Fig. 2). The number of individuals of the three turaco species encountered differed significantly among the camps of the KCA (ANOVA $\mathrm{F}_{3.18}=12.21, P<0.05$ ). The total number of individuals of each of the three turaco species recorded in the three seasons during the study differed significantly $\left(\mathrm{F}_{2,18}=14.29, P<0.05\right)$ (Table 2).

There was a highly significant difference between the two habitat types in the abundance of the various turaco species encountered (ANOVA $\mathrm{F}_{1,51}=17.79, P<0.05$ ). More individuals of the species were encountered in the primary than the secondary forest. Out of the total of 13 individuals of Corythaeola cristata recorded in the forest near Antwikwaa, eight were recorded in the primary forest and five in the secondary. These patterns run through all the camps for the other two species, except at Adiembra where the pattern was reversed for T. persa and T. macrorynchus (Table 3).

TABLE 3

Average number of individual turacos encountered in the various habitat types in the KCA (Prim.-Primary forest, Sec.-Secondary forest)

Turaco species

Habitat type

\begin{tabular}{ccccc}
\multicolumn{2}{c}{ Abrafo } & Antwikwaa & Briscoe 2 & Adiembra \\
Prim. Sec. & Prim. Sec. & Prim. Sec. Prim. Sec.
\end{tabular}

West African Journal of Applied Ecology - Volume 13 


$\begin{array}{lrrrrrrrr}\text { Corythaeola cristata } & 4 & 0 & 8 & 5 & 0 & 0 & 0 & 0 \\ \text { Tauraco persa } & 25 & 11 & 29 & 13 & 29 & 5 & 11 & 12 \\ \text { Tauraco macrorynchus } & 15 & 6 & 13 & 11 & 18 & 2 & 4 & 9\end{array}$

\section{Encounter rates of turacos}

Table 4 shows the encounter rates of the three species in the forests near the camps of the KCA. The encounter rate of $T$. persa was the highest, ranging between 3.7 individuals/h in Adiembra to 7.0 individuals/h in Antwikwaa. The encounter rates of T. macrorynchus ranged between 2.2 individuals $/ \mathrm{h}$ at Adiembra to 4.0 individuals/h at Antwikwaa. The rate at which $C$. cristata was encountered was generally low, compared to the other species in all the study sites. At Antwikwaa area the encounter rate was 2.2 individuals/ $\mathrm{h}$, reducing to 0.7 individuals/ $\mathrm{h}$ in Abrafo and zero in Briscoe II and Adiembra. The lowest encounter rates for T. persa and T. macrorynchus were at Adiembra while the highest were at Antwikwaa (Table 4). The encounter rates, however, varied between the two vegetation types with the primary vegetation recording higher rates than secondary $\left(\right.$ ANOVA $\left._{2,18}=93.82, P<0.05\right)$ (Table 5).

TABLE 4

Encounter rates of turaco species in the forests near the camps (study sites) (Figures in brackets are numbers of encounters)

\begin{tabular}{lllll} 
Turaco species & Abrafo & \multicolumn{2}{l}{ Encounter rates (individuals $/$ ) } & \\
& & Antwikwaa & Briscoe II & Adiembra \\
Corythaeola cristata & $0.67(144)$ & $2.17(468)$ & 0 & 0 \\
Tauraco persa & $5.84(1260)$ & $7.00(1512)$ & $5.67(1224)$ & $3.67(792)$ \\
Tauraco macrorynculus & $3.50(756)$ & $4.00(864)$ & $3.34(720)$ & $2.17(468)$
\end{tabular}

TABLE 5

Encounter rates of turacos species within the two habitat types

\begin{tabular}{|c|c|c|c|c|c|c|c|c|}
\hline \multirow[t]{3}{*}{ Turaco species } & \multicolumn{8}{|c|}{ Encounter rates per habitat types of the camps (individuals $/ h$ ) } \\
\hline & \multicolumn{3}{|c|}{ Antwikwaa } & \multicolumn{2}{|c|}{ Briscoe II } & \multicolumn{2}{|c|}{ Adiembra } & \multirow[b]{2}{*}{ Sec. } \\
\hline & Prim & Sec. & Prim. & Sec. & Prim. & Sec. & Prim. & \\
\hline $\begin{array}{l}\text { Corythaeola } \\
\text { cristata }\end{array}$ & $0.67(144)$ & 0 & $1.34(288)$ & $0.84(180)$ & 0 & 0 & 0 & 0 \\
\hline $\begin{array}{l}\text { Tauraco } \\
\text { persa }\end{array}$ & $4.17(900)$ & $1.67(360)$ & $4.84(1044)$ & $2.17(468)$ & $4.84(1044)$ & $0.84(180)$ & $1.84(396)$ & $2.00(432)$ \\
\hline Tauraco & $2.50(540)$ & $1.00(540)$ & $2.17(216)$ & $1.84(468)$ & $3.00(648)$ & $0.34(72)$ & $0.67(144)$ & $1.50(324)$ \\
\hline
\end{tabular}

\section{Discussion}

The difference in the degree of abundance (Fig. 2) and encounter rates (Table 4) of the three turaco species in the various camps may be attributed to factors such as human activities and the variation in the forest structure. Even though the forest at all camps (study sites) seemed similar with a fair distribution of the most popular turaco food trees, there are some basic variations in the structure of the forest at the various camps. Antwikwaa forest seemed better conserved with large emergents in the upper canopy, creating good resting and feeding grounds for the great blue turacos since they are known to be upper West African Journal of Applied Ecology - Volume 13 
canopy species (Bryant, 1979; Brooke, 1979; Brown et al., 1982). A similar vegetation structure was observed in the secondary forest at Abrafo; hence both camp forests recorded some numbers of great blue turacos.

The middle layer also formed closed canopies in these areas, creating a more comfortable habitat for survival of the other two species, hence the larger numbers recorded. The absence of great blue turacos in the forest of Briscoe II and Adiembra areas could probably be due to a combination of heavy human influx in the area and the absence of long stretches and aggregates of suitable tall trees. Brosset \& Fry (1988) confirmed that great blue turacos almost always moved on the tallest trees and, thus, avoided the low canopy areas. Also, Dowset-Lemaire (1990) confirmed that great blue turacos exist in the highest elevations in the forest while the green and yellow-billed turacos occupy the mid elevation range of the forest and were found to be agile, shy and secretive. Differential preference for habitats, thus, seems to play a major role in the peculiar distribution patterns.

The seasonal differences observed may be due to the fact that turaco food was scarce in one season and abundant in the other. During the dry season, the number of individuals encountered reduced, probably because most fruit plants were not fruiting and so turacos moved to the interior of the reserve to other foraging grounds to obtain food. Dowset-Lemaire (1990) established that turacos exist mainly at higher levels in trees, only coming down a few times to lower levels to avoid interference from other animals and occasionally move in search for food during food scarcity, especially in the dry season when most fruit trees were not fruiting. Habitat destruction and hunting may be the most probable reasons for the fewer numbers encountered in some camps. Apart from the green- and yellow-billed turacos that seemed to be in larger numbers, the great blue turaco numbers are low, and this must be given some serious attention.

A study of the usual locations and hideouts of turacos of KCA as the basis for the establishment of possible watching points for tourists was one of the objectives of this study. It was realized that the turacos, like any other group of birds, are cosmopolitan and this would hinder the exploitation of this potential for tourism. No permanent locations of the turacos could be established. In fact, it was found that feeding places changed from day to day and from time to time. It was, however, established that, if their places of recent feeding (especially where clusters of fruiting trees of their preference existed) could be located, then one could encounter the species.

Indicators such as the calls and charac-teristic flapping of the wings of turacos could be used to detect their presence. Tourists could use the research transects made in the various camp areas as permanent trails for watching turacos and other birds. Tourist turaco-watchers must be aware that early mornings (5.00 h GMT - $9.30 \mathrm{~h} \mathrm{GMT)} \mathrm{and} \mathrm{late} \mathrm{afternoons} \mathrm{(3.00} \mathrm{h} \mathrm{GMT} \mathrm{-} \mathrm{5.30} \mathrm{h} \mathrm{GMT)} \mathrm{are} \mathrm{appropriate} \mathrm{times} \mathrm{for}$ sighting turacos. Primary vegetation is a better turaco sighting point than the secondary. Possible GPS locations of turacos (near clusters of preferred food trees) were extrapolated on the map of the KCA to guide tourist bird-watchers interested in the turaco species (Fig. 1). Among all the forest camps, a deeper walk in Atwikwaa and Abrafo areas was found to be the best place for sighting turacos.

\section{Conclusion}

Findings from this study indicate that the population of the great blue turaco (Corythaeola cristata), the largest of the three turacos, is very low (0-20 individuals over a time effort of $18 \mathrm{~h}$ per camp site per season) in the Kakum Conservation Area. There is, therefore, the need to investigate the possible factors, such as over-harvesting and food availability, that threaten the survival of these birds to enable appropriate mitigating measures to be put in place. It is also recommended that the problem of reduction in turaco numbers should be effectively tackled, otherwise, any attempt to exploit their tourism potential will be stifled. In addition a comprehensive study of the ecology of all the three species of turacos should be undertaken to facilitate their conservation in the area.

\section{Acknowledgement}

West African Journal of Applied Ecology - Volume 13 
The authors acknowledge with thanks the help provided by the staff of the Kakum National Park and Ghana Wildlife Society during the field work.

\section{References}

Bibby C., Jones M. and Marsden S. (1998). Expedition Field Techniques: Bird Surveys. Expedition Advisory Centre, London. p. 135.

Birdlife International (2004). State of the World's Birds 2004: Indicators for our Changing World. Birdlife International, Cambridge. p. 18.

Borrow N. and Demey, R. (2001). Birds of Western Africa. Christopher Helm Publishers, London. pp. 138-484.

Brooke M. de L. (1979). Differences in the quality of territories held by wheatears (Oenanthe oenanthe) J. Anim. Ecol.48, 2132.

Brosset A. and Fry C. H. (1988). Order Musophagiformes. In The Birds of Africa. (C. H. Fry, S. Keith and E. K. Urban, ed.), pp. 26-57. Academic Press, San Diego, California.

Brown L. H., Urban E. K. and Newman K. (1982). The Birds of Africa, vol. 1. Academic Press, London.

Bryant D. M. (1979). Reproductive costs in the house martin. J. Anim. Ecol. 48: 655-675.

Dowsett-Lemaire F. (1983). Ecological and territorial requirements of montane forest birds on the Nyika Plateau, South Central Africa. Gerfaut 73: 345-378.

Dowsett-Lemaire F. (1990). Eco-ethology, Distribution and Status of Nyungwe Forest Birds (Rwanda). In Survey of the Fauna and Flora of Nyungwe Forest, Rwanda. (R. J. Dowsett, ed.), pp. 31-85. Tauraco Press, Ely, United Kingdom.

Grimes L.G. (1987) The Birds of Ghana. British Ornithologists Union, London.

Hall J. B. and Swaine M. D. (1981). Distribution and Ecology of Vascular Plants in Tropical Rainforest: Forest Vegetation of Ghana. W. Junk Publishers, The Hague. 383 pp.

Hanzak J. (1974). The Pictorial Encyclopaedia of Birds, 5th edn. Bruce Campbell. Publishers. pp. 340-349.

Mensah-Ntiamoah A. Y. (1989). Pre-feasibility studies on wildlife potentials in the Kakum and Assin-Attandanso Forest Reserves, Central Region-Ghana. Wildlife Division of the Forestry Commission, Accra. 46 pp.

Perrins C. M. and Birkhead T. R. (1983). Avian Ecology. Blackie, New York. 221 pp.

Verheyen R. (1956). Contribution a l'anatomie et a la systematique des touracos (Musophagi) et des coucous (Cuculiformes). Bull. Inst. r. Sci. nat. Belg. 32: 28-34. 